\title{
Engineered mRNA and the Rise of Next-Generation Antibodies
}

\author{
Laura Sanz ${ }^{1, * \mathbb{D}}$ and Luis Álvarez-Vallina $2,3, *$ (D) \\ 1 Molecular Immunology Unit, Hospital Universitario Puerta de Hierro Majadahonda, 28220 Madrid, Spain \\ 2 Cancer Immunotherapy Unit (UNICA), Department of Immunology, Hospital Universitario12 de Octubre, \\ 28041 Madrid, Spain \\ 3 Immuno-Oncology and Immunotherapy Group, Instituto de Investigación Sanitaria 12 de Octubre (imas12), \\ 28041 Madrid, Spain \\ * Correspondence: 1salcober@salud.madrid.org (L.S.); lav.imas12@h12o.es (L.Á.-V.)
}

check for

updates

Citation: Sanz, L.; Álvarez-Vallina, L Engineered mRNA and the Rise of Next-Generation Antibodies. Antibodies 2021, 10, 37. https:// doi.org/10.3390/antib10040037

Academic Editor: Simon E. Hufton

Received: 10 August 2021

Accepted: 22 September 2021

Published: 26 September 2021

Publisher's Note: MDPI stays neutral with regard to jurisdictional claims in published maps and institutional affiliations.

Copyright: (c) 2021 by the authors. Licensee MDPI, Basel, Switzerland. This article is an open access article distributed under the terms and conditions of the Creative Commons Attribution (CC BY) license (https:/ / creativecommons.org/licenses/by/ $4.0 /)$.

\begin{abstract}
Monoclonal antibodies are widely used as therapeutic agents in medicine. However, clinical-grade proteins require sophisticated technologies and are extremely expensive to produce, resulting in long lead times and high costs. The use of gene transfer methods for in vivo secretion of therapeutic antibodies could circumvent problems related to large-scale production and purification and offer additional benefits by achieving sustained concentrations of therapeutic antibodies, which is particularly relevant to short-lived antibody fragments and next-generation, Fc-free, multispecific antibodies. In recent years, the use of engineered mRNA-based gene delivery has significantly increased in different therapeutic areas because of the advantages it possesses over traditional gene delivery platforms. The application of synthetic mRNA will allow for the avoidance of manufacturing problems associated with recombinant proteins and could be instrumental in consolidating regulatory approvals for next-generation therapeutic antibodies.
\end{abstract}

Keywords: RNA; engineered mRNA; antibody fragments; multispecific antibodies; next-generation antibodies

\section{Introduction}

In 2005, Philipp Holliger and Peter J. Hudson published a seminal review entitled "Engineered antibody fragments and the rise of single domains" [1] where the authors foresaw "a burgeoning range of regulatory approvals for recombinant monoclonal antibody $(\mathrm{mAb})$ fragments in diagnosis and therapy". There was a range of applications in which the Fc (fragment crystallizable)-mediated effects were not required. Recombinant antibody fragments, such as Fab (antigen-binding fragment), scFv (single-chain variable fragment), and single-domains ( $\mathrm{V}_{\mathrm{HH}}$ antibodies, also known as nanobodies), offered unprecedented advantages, such as increased tumor penetration [2] and/or binding to epitopes inaccessible for the large and flat antigen-binding sites of conventional antibodies [3,4].

Fifteen years later, this prediction has not been fulfilled. If we take a look at the antibody-based therapeutics approved or in revision devoid of the Fc region, they are still a minority. Only 10 out of 120 are not based on canonical IgG formats as of September 2021 (Table 1). This short list includes four Fabs; one scFv; two scFv-based immunotoxins; a bispecific tandem $(\mathrm{scFv})_{2}$, also known as 'bispecific T cell engager' (BiTE); one monospecific bivalent nanobody, and a soluble T cell receptor (TCR) fused to a scFv. Removal of the Fc domain is a standard approach to prevent adverse immune effects, but with the caveat of abolishing Fc-driven cellular recycling via neonatal $F_{c}$ receptor ( $\left.F c R n\right)$ engagement, which leads to a significant reduction in blood residence time [1,5]. Alternatively, antibody fragments can be introduced into enclosed locations where rapid renal clearance is not an issue. This is the case for vascular endothelial growth factor (VEGF) blockers ranibizumab (Fab) and brolucizumab (scFv), which are used for the treatment of age-related macular degeneration and administered by intravitreal injection. The scenario in late-stage antibodies is no better: 5 out of 99 (Table 2), practically half the percentage. Even non-conventional 
formats such as bispecific antibodies mostly retain their Fc regions, and platforms that were initially designed Fc free have included silenced Fc domains in their most recent designs in an attempt to extend their circulatory half-life, such as the HLE (half-life extended) BiTE and [6] Fc-DART (Dual-Affinity Re-Targeting) antibodies [7].

Table 1. Fc-free antibody-based therapeutics approved or in review (EU/US).

\begin{tabular}{|c|c|c|c|c|}
\hline $\begin{array}{l}\text { Non-Proprietary } \\
\text { Name }\end{array}$ & Target & Format & Indication First Approved & $\begin{array}{c}\text { First Approval } \\
\text { Year (EU/US) }\end{array}$ \\
\hline Abciximab & GPIIb/IIIa & Chimeric Fab & $\begin{array}{c}\text { Prevention of blood clots in } \\
\text { angioplasty }\end{array}$ & $1995 * / 1994$ \\
\hline Ranibizumab & VEGF & Humanized Fab & Macular degeneration & $2007 / 2006$ \\
\hline Certolizumab pegol & TNF & Humanized Fab, pegylated & Crohn disease & $2009 / 2008$ \\
\hline Blinatumomab & $\mathrm{CD} 19 \times \mathrm{CD} 3$ & $\begin{array}{l}\text { Murine bispecific tandem } \\
\text { scFv }\end{array}$ & $\begin{array}{c}\text { Acute lymphoblastic } \\
\text { leukemia }\end{array}$ & $2015 / 2014$ \\
\hline Idarucizumab & Dabigatran & Humanized Fab & $\begin{array}{c}\text { Reversal of } \\
\text { dabigatran-induced } \\
\text { anticoagulation }\end{array}$ & $2015 / 2015$ \\
\hline $\begin{array}{l}\text { Moxetumomab } \\
\text { pasudotox }\end{array}$ & $\mathrm{CD} 22$ & $\begin{array}{l}\text { Murine scFv }+\mathrm{PE} \\
\text { immunotoxin }\end{array}$ & Hairy cell leukemia & $2021 / 2018$ \\
\hline Caplacizumab & vWF & Humanized bivalent $\mathrm{V}_{\mathrm{HH}}$ & $\begin{array}{c}\text { Acquired thrombotic } \\
\text { thrombocytopenic purpura }\end{array}$ & $2018 / 2019$ \\
\hline Brolucizumab & VEGF-A & Humanized scFv & Macular degeneration & $2020 / 2019$ \\
\hline Oportuzumab monatox & EpCAM & $\begin{array}{l}\text { Humanized } \mathrm{scFv}+\mathrm{PE} \\
\text { immunotoxin }\end{array}$ & Bladder cancer & NA/In review \\
\hline Tebentafusp & gp100, CD3 & Soluble TCR + scFv ImmTAC & Uveal melanoma & $\begin{array}{l}\text { In review } / \text { In } \\
\text { review }\end{array}$ \\
\hline
\end{tabular}

Abbreviations: EpCAM, epithelial cell adhesion molecule; Fab, antigen-binding fragment; GPIIb/IIIa, glycoprotein IIb/IIIa; ImmTAC: immune-mobilizing monoclonal TCR against cancer; PE, Pseudomonas exotoxin A; scFv, single-chain variable fragment; TCR, T cell receptor; TNF, tumor necrosis factor; VEGF-A, vascular endothelial growth factor-A; vWF, von Willebrand factor; ${ }^{*}$, country-specific approval. Adapted from The Antibody Society. Therapeutic monoclonal antibodies approved or in review in the EU or US. Available online: https://www.antibodysociety.org/resources/approved-antibodies (accessed on 23 September 2021).

Table 2. Fc-free antibody-based therapeutics in late-stage clinical trials.

\begin{tabular}{|c|c|c|c|c|c|}
\hline Company & $\begin{array}{l}\text { INN or Code } \\
\text { Name }\end{array}$ & Molecular Format & Target & $\begin{array}{c}\text { Most Advanced } \\
\text { Phase }\end{array}$ & Indications \\
\hline MacroGenics & $\begin{array}{l}\text { Flotetuzumab } \\
\text { (MGD006) }\end{array}$ & $\begin{array}{c}\text { Humanized } \\
\text { bispecific DART }\end{array}$ & CD123, CD3 & Phase 2 (pivotal) & $\begin{array}{c}\text { Acute myeloid leukemia } \\
\text { (NCT02152956, } \\
\text { NCT04582864) }\end{array}$ \\
\hline Affimed N.V. & AFM13 & $\begin{array}{c}\text { Human-bispecific } \\
\text { T TandAb }\end{array}$ & CD30, CD16A & Phase 2 (pivotal) & $\begin{array}{l}\text { Peripheral T Cell } \\
\text { lymphoma } \\
\text { (NCT04101331) }\end{array}$ \\
\hline Philogen SpA & $\begin{array}{c}\text { Onfekafusp alfa, } \\
\text { (L19IL2 + L19TNF) }\end{array}$ & $\begin{array}{c}\text { scFv-based } \\
\text { immunocytokines }\end{array}$ & $\begin{array}{c}\text { Fibronectin EDB } \\
\text { domain }\end{array}$ & Phase 3 & Melanoma (NCT03567889) \\
\hline $\begin{array}{c}\text { PhaseBio Phar- } \\
\text { maceuticals }\end{array}$ & $\begin{array}{l}\text { Bentracimab } \\
\text { (PB2452) }\end{array}$ & Human Fab & Ticagrelor & Phase 3 & $\begin{array}{l}\text { Reversal of the antiplatelet } \\
\text { effects of ticagrelor } \\
\text { (NCT04286438) }\end{array}$ \\
\hline $\begin{array}{c}\text { Taisho } \\
\text { Pharmaceutical }\end{array}$ & Ozoralizumab & $\begin{array}{l}\text { Humanized } \\
\text { bispecific } \\
\text { nanobody }\end{array}$ & TNF, albumin & Phase 3 & $\begin{array}{c}\text { Rheumatoid arthritis } \\
\text { (JapicCTI-184031, } \\
\text { NCT04077567) }\end{array}$ \\
\hline
\end{tabular}

Abbreviations: DART, dual-affinity re-targeting antibody; EDB, extradomain-B (fibronectin); Fab, antigen-binding fragment; IL2, interleukin2; scFv, single-chain Fv; TandAb, tandem diabody; TNF, tumor necrosis factor. Adapted from The Antibody Society. Monoclonal antibodies in late-stage clinical studies. Available online: https://www.antibodysociety.org/members-only/late-stage-clinical-pipeline/ (accessed on 23 September 2021). 


\section{The Challenges of Antibody Fragment Development}

What was wrong, then, with Holliger and Hudson's prediction? Was the incorporation of Fc domains the only option to increase the half-life of antibodies? Or was industry reluctant to change its manufacturing procedures? Several studies have shown that it is possible to extend the half-life of antibody fragments through fusion with albuminbinding peptides [8] or proteins [9-11]. Half-life extension of nanobodies via fusion to an albumin-binding nanobody has been demonstrated in different species in preclinical studies [12]. In addition, vobarilizumab (formerly ALX-0061) reached a phase $2 \mathrm{~b}$ clinical trial in patients with moderate to severe rheumatoid arthritis, demonstrating a positive impact on disease activity [13]. Vobarilizumab is a bispecific nanobody with a high affinity for the IL-6 receptor, combined with an extended half-life by targeting human serum albumin (HSA). An apparent plasma half-life of 6.6 days was observed after a single intravenous administration of $10 \mathrm{mg} / \mathrm{kg}$ ALX-0061 in non-human primates, similar to the estimated expected half-life of HSA [14]. Ozoralizumab (ATN-103, TS-152), a trivalent, bi-specific nanobody that potently neutralizes tumor necrosis factor alpha (TNF $\alpha)$ and binds to HSA to increase its in vivo half-life is in late-stage clinical trials (phase 3) [15] and has been submitted for approval in Japan (2021). An anti-hepatocyte growth factor nanobody has also been molecularly fused to an albumin-binding nanobody unit to obtain serum half-life extension [16].

In addition, multimerization of antibody fragments can increase molecular weight far above the renal cut-off. AFM13, a tetravalent bispecific anti-CD30 $\mathrm{x}$ anti-CD16A TandAb (tandem diabody), with a molecular weight of around $100 \mathrm{kDa}$, is in phase 2 trials for the treatment of peripheral T cell lymphoma [17]. Bispecific anti-CD137 $x$ anti-EGFR (epidermal growth factor receptor) trimerbodies, with a molecular weight of $160 \mathrm{kDa}$, have been able to eradicate established tumors in several animal models $[18,19]$. Therefore, it seems that half-life extension and multimerization strategies would provide Fc-free antibodies with potential for therapeutic opportunities. However, these next-generation antibody therapeutics have faced major bottlenecks in their development, probably associated with challenges in manufacturing, formulation, and stability of clinical grade products. Canonical mAbs are routinely produced in Chinese hamster ovary $(\mathrm{CHO})$ cells, and the majority of purification processes involve protein A-based chromatography, which results in a high degree of purity and recovery in a single step [20]. These procedures provide yields of grams per liter per hour with full-length IgG-based antibodies, which are difficult to achieve with antibody fragments. Adapting proven antibody purification processes to antibody fragments requires different affinity chromatography methods, such as protein $\mathrm{L}$, although a protein L-based production platform may not accommodate all antibody fragments [21].

\section{Antibody Gene Therapy: A Critical Step toward Clinical Application}

An alternative proposed two decades ago was the use of gene-based strategies for in vivo production of antibody fragments [22-24]. In 2004, we published a review entitled "Antibodies and gene therapy: teaching old 'magic bullets' new tricks" [25] where, we claimed that in vivo production of antibody fragments could result in effective and persistent serum levels compensating for their rapid blood clearance. Furthermore, in vivo secretion could circumvent some of the challenges associated with large-scale production of recombinant antibodies and potentially allow for the design and generation of more complex antibody molecules that may exhibit an improved therapeutic index [26-28]. One of the most promising cancer immunotherapy strategies is based on redirecting the activity of $\mathrm{T}$ cells using bispecific antibodies, enabling the bridging of cytotoxicity-triggering receptors with a selected tumor-associated antigen (TAA) [26]. TAA-specific T cell-engaging (TCE) bispecific antibodies have revealed outstanding clinical results in some hematological cancers [29]. However, Fc-free BiTEs have a short serum half-life compared with full-length IgG antibodies, and continuous intravenous administration via infusion pumps is necessary to achieve therapeutic serum levels [30]. In 2003, our group reported for 
the first time a cancer immunotherapy strategy based on the in vivo secretion of a TCEbispecific antibody [24]. We demonstrated that human cells could be engineered to secrete a functionally active anti-CEA $x$ anti-CD3 Fc-free diabody, which redirects primary $T$ cell cytotoxicity in a CEA-dependent manner and delays the growth rate of human colorectal cancer xenografts in mice [24]. Since then, we have validated this bispecific antibody-based gene therapy strategy using different formats of bispecific antibodies (diabody and BiTE), various types of cell carriers (human T cells, human mesenchymal and hematopoietic stem cells, and human endothelial cells), several gene transfer systems (plasmid DNA and lentiviral vectors), and several mouse cancer models [31-36]. Recently, other groups have demonstrated encouraging therapeutic effects in preclinical models of cancer using TCEsecreting T cells engineered with viral vectors [37-39], as well as CAR-T cells produced by mRNA technology [40].

\section{Engineered mRNA: The Last Frontier}

In recent years, mRNA-based gene delivery has significantly increased in different therapeutic areas because of the advantages that it possesses over traditional gene delivery platforms (e.g., viral vectors and plasmid DNA) [41,42]. Synthetic mRNA is a short-lived genetic carrier and does not need to enter the cell nucleus for efficient, rapid, and transient protein expression, even in nondividing cells, so there is no risk of insertion into the host genome [43], and it is not hampered by any pre-existing immunity as in the case of viral vectors [44]. However, mRNA can induce Toll-like receptor (TLR)-dependent activation of the innate immune system, thereby affecting the utility of unmodified mRNA-based therapeutics in vivo. Exogeneous mRNA can be sensed by TLRs in the endosomes as well as by receptors such as RIG-I and MDA5, in the cytosol. While improved immune activation can be of interest in vaccination strategies, innate immune sensing can also create an unfavorable environment for the translation of mRNA and thus limit protein expression [45]. The incorporation of modified nucleosides, such as pseudouridine and 5 -methylcytidine, in engineered mRNA prevents immune activation and increases the stability and translation of mRNA [46,47]. These chemical modifications, together with efficient delivery methods, such as the use of lipid nanoparticles, have enormously simplified and expanded the use of mRNA for therapeutic applications [48]. One study reported that intravenous administration of engineered mRNA encoding bispecific anti-TAA $x$ anti-CD3 BiTEs induced sustained secretion of functional antibodies, which eliminated established human tumors in mice as effectively as systemically administered purified BiTEs [49]. Despite the interest in mRNA research for therapeutic applications, only a few pre-clinical studies have been reported for mRNA-encoded antibody fragments (Table 3); for full length antibodies, see Deal CE et al. [48]. The first phase 1 clinical trial of an mRNA-encoded antibody [50] has recently been completed, and the results demonstrate the safety of this approach and the potential to reach appropriate levels of circulating antibodies [51].

The use of mRNA-based gene delivery platforms will be critical to the widespread clinical application of short-lived Fc-free next-generation antibodies: multivalent and multispecific molecules with a format adapted to the pathological context [5,52]. Unlike systemic administration of purified antibodies, mRNA-based delivery may result in expression for several days and sustained plasma levels, which may allow less frequent dosing when prolonged treatments are required. In addition, the use of synthetic mRNA will allow for the avoidance of manufacturing problems associated with recombinant antibody fragments and next-generation multispecific antibodies, and it is more cost-effective, faster, and flexible to produce. However, for the use of mRNA-encoded antibodies as a competitive therapeutic product and a viable alternative to purified antibodies, further optimization steps are necessary, such as improving formulation technology to reach effective antibody levels and enhanced tolerability, as well as the use of other routes of administration (e.g., intramuscular and subcutaneous) for improved convenience and reduced therapy costs. In addition, targeted delivery of the mRNA to the tissue/organ of interest (e.g., intranasal, 
intratracheal, or intratumoral) could decrease potential systemic toxicity and reduce the amount of mRNA required to reach therapeutic levels.

Table 3. mRNA-encoded antibody fragments in preclinical studies.

\begin{tabular}{|c|c|c|c|c|c|}
\hline Antibody & Target & Format & Model & Outcome & Ref \\
\hline RiboMABs & $\begin{array}{c}\text { CD3 } \times \text { CLDN6 } \\
\text { CLDN18.2 } \times \text { CD3 } \\
\text { EpCAM } \times \text { CD3 } \\
\text { CD3 } \times(\text { CLDN6 })_{2}\end{array}$ & $\begin{array}{c}\mathrm{Bs}(\mathrm{scFv})_{2} \\
\mathrm{Fab}-(\mathrm{scFv})_{2}\end{array}$ & $\begin{array}{c}\text { Human PBMC-engrafted } \\
\text { NSG mice bearing s.c. } \\
\text { human ovarian cancer } \\
\text { xenografts }\end{array}$ & $\begin{array}{l}\text { Eradication of tumors } \\
\left(200-300 \mathrm{~mm}^{3}\right) \text { after one. i.v. } \\
\text { infusion a week for } 3 \text { weeks }\end{array}$ & [49] \\
\hline VNA-BoNTA & $\begin{array}{c}\text { Botulism } \\
\text { neurotoxin A }\end{array}$ & $\mathrm{Bp}\left(\mathrm{V}_{\mathrm{HH}}\right)_{2}+\mathrm{ABP}$ & $\begin{array}{c}\text { CD1 mice receiving a lethal } \\
\text { dose of BoNTA }\end{array}$ & $\begin{array}{l}\text { Survival when treated up to } \\
6 \mathrm{~h} \text { post-intoxication with i.v. } \\
\text { VNA-BoNTA }\end{array}$ & [52] \\
\hline VNA-Stx2 & E. coli Shiga toxin & $\mathrm{Bs}\left(\mathrm{V}_{\mathrm{HH}}\right)_{2}+\mathrm{ABP}$ & $\begin{array}{c}\text { CD1 mice receiving a lethal } \\
\text { dose of BoNTA }\end{array}$ & $\begin{array}{l}\text { Negative control. No } \\
\text { surviving mice in this group }\end{array}$ & [52] \\
\hline RSV aVHH & RSV F protein & $\mathrm{V}_{\mathrm{HH}}+\mathrm{GPI}$ anchor & $\begin{array}{l}\text { BALB / c mice inoculated i.n. } \\
\text { with RSV } 1 \text { day } \\
\text { post-treatment }\end{array}$ & $\begin{array}{l}\text { RSV titers significantly } \\
\text { lower after i.t. aerosol } \\
\text { mRNA administration }\end{array}$ & [53] \\
\hline RiboBiFE & $\begin{array}{l}\text { Mouse Fc } \gamma \text { RIV x } \\
\text { influenza A M2e }\end{array}$ & Bs $\left(V_{\mathrm{HH}}\right)_{2}$ & $\begin{array}{l}\text { C57BL/ } 6 \text { mice challenged } \\
\text { with i.n. lethal dose of } \\
\text { influenza virus } 4 \mathrm{~h} \\
\text { post-treatment }\end{array}$ & $\begin{array}{c}100 \% \text { survival in wild-type } \\
\text { mice receiving i.t. mRNA, } \\
0 \% \text { in mice Fc } \gamma \mathrm{RIV}^{-/-}\end{array}$ & [54] \\
\hline
\end{tabular}

Abbreviations: ABP, albumin-binding peptide; BoNTA, botulism neurotoxin A; Bp, biparatopic; Bs, bispecific; CLDN, claudin; EpCAM, epithelial cell adhesion molecule; Fab, antigen-binding fragment GPI, glycosylphosphatidylinositol; i.n., intranasal; i.t., intratracheal; i.v., intravenous; PBMC, peripheral blood mononuclear cell; RiboBiFE, mRNA-encoded bispecific Fc-receptor engaging; RiboMAB, mRNA-encoded antibody; RSV, respiratory syncytial virus; M2e, matrix protein 2 ectodomain; VNA, VHH-based neutralizing agent.

Author Contributions: Conceptualization, L.S. and L.Á.-V.; writing-original draft preparation, L.S. and L.Á.-V. writing-review and editing, L.S. and L.Á.-V.; funding acquisition, L.S. and L.Á.-V. Both authors have read and agreed to the published version of the manuscript.

Funding: Financial support for this work was obtained from the Spanish Ministry of Science and Innovation (SAF2017-89437-P to L.Á.-V.), partially supported by the European Regional Development Fund (ERDF); the Carlos III Health Institute (ISCIII, PI19/00132 to L.S.), partially supported by the ERDF; the Spanish Association Against Cancer (AECC 19084 to L.Á.-V.); and the CRIS Cancer Foundation (FCRIS-2018-0042 and FCRIS-2021-0090 to L.Á.-V.).

Institutional Review Board Statement: Not applicable.

Informed Consent Statement: Not applicable.

Data Availability Statement: Not applicable.

Conflicts of Interest: The authors declare no conflict of interest.

\section{References}

1. Holliger, P.; Hudson, P.J. Engineered antibody fragments and the rise of single domains. Nat. Biotechnol. 2005, 23, 1126-1136. [CrossRef] [PubMed]

2. Sanz, L.; Cuesta, A.M.; Compte, M.; Alvarez-Vallina, L. Antibody engineering: Facing new challenges in cancer therapy. Acta Pharmacol. Sin. 2005, 26, 641-648. [CrossRef] [PubMed]

3. Klein, J.S.; Gnanapragasam, P.N.; Galimidi, R.P.; Foglesong, C.P.; West, A.P., Jr.; Bjorkman, P.J. Examination of the contributions of size and avidity to the neutralization mechanisms of the anti-HIV antibodies b12 and 4E10. Proc. Natl. Acad. Sci. USA 2009, 106, 7385-7390. [CrossRef] [PubMed]

4. Rossey, I.; Gilman, M.S.; Kabeche, S.C.; Sedeyn, K.; Wrapp, D.; Kanekiyo, M.; Chen, M.; Mas, V.; Spitaels, J.; Melero, J.A.; et al. Potent single-domain antibodies that arrest respiratory syncytial virus fusion protein in its prefusion state. Nat. Commun. 2017, 8 , 14158. [CrossRef] [PubMed]

5. Cuesta, A.M.; Sainz-Pastor, N.; Bonet, J.; Oliva, B.; Alvarez-Vallina, L. Multivalent antibodies: When design surpasses evolution. Trends Biotechnol. 2010, 28, 355-362. [CrossRef] [PubMed]

6. Deegen, P.; Thomas, O.; Nolan-Stevaux, O.; Li, S.; Wahl, J.; Bogner, P.; Aeffner, F.; Friedrich, M.; Liao, M.Z.; Matthes, K.; et al. The PSMA-targeting Half-life Extended BiTE Therapy AMG 160 has Potent Antitumor Activity in Preclinical Models of Metastatic Castration-resistant Prostate Cancer. Clin. Cancer Res. 2021, 27, 2928-2937. [CrossRef] 
7. Liu, L.; Lam, C.K.; Long, V.; Widjaja, L.; Yang, Y.; Li, H.; Jin, L.; Burke, S.; Gorlatov, S.; Brown, J.; et al. MGD011, A CD19 x CD3 Dual-Affinity Retargeting Bi-specific Molecule Incorporating Extended Circulating Half-life for the Treatment of B-Cell Malignancies. Clin. Cancer Res. 2017, 23, 1506-1518. [CrossRef]

8. Dennis, M.S.; Zhang, M.; Meng, Y.G.; Kadkhodayan, M.; Kirchhofer, D.; Combs, D.; Damico, L.A. Albumin binding as a general strategy for improving the pharmacokinetics of proteins. J. Biol. Chem. 2002, 277, 35035-35043. [CrossRef]

9. Dennis, M.S.; Jin, H.; Dugger, D.; Yang, R.; McFarland, L.; Ogasawara, A.; Williams, S.; Cole, M.J.; Ross, S.; Schwall, R. Imaging tumors with an albumin-binding Fab, a novel tumor-targeting agent. Cancer Res. 2007, 67, 254-261. [CrossRef]

10. Tijink, B.M.; Laeremans, T.; Budde, M.; Stigter-van Walsum, M.; Dreier, T.; de Haard, H.J.; Leemans, C.R.; van Dongen, G.A. Improved tumor targeting of anti-epidermal growth factor receptor Nanobodies through albumin binding: Taking advantage of modular Nanobody technology. Mol. Cancer Ther. 2008, 8, 2288-2297. [CrossRef]

11. Andersen, J.T.; Pehrson, R.; Tolmachev, V.; Daba, M.B.; Abrahmsén, L.; Ekblad, C. Extending half-life by indirect targeting of the neonatal Fc receptor (FcRn) using a minimal albumin binding domain. J. Biol. Chem. 2011, 286, 5234-5241. [CrossRef]

12. Hoefman, S.; Ottevaere, I.; Baumeister, J.; Sargentini-Maier, M.L. Pre-Clinical Intravenous Serum Pharmacokinetics of Albumin Binding and Non-Half-Life Extended Nanobodies. Antibodies 2015, 4, 141-156. [CrossRef]

13. Dorner, T.; Weinblatt, M.; Van Beneden, K.; Dombreccht, E.J.; De Beuf, K.; Schoen, P.; Zeldon, R.K. FRI0239 Results of a phase 2b study of vobarilizumab, an anti-interleukin-6 receptor nanobody, as monotherapy in patients with moderate to severe rheumatoid arthritis. Ann. Rheum. Dis. 2017, 76 (Suppl. 2), 575. [CrossRef]

14. Van Roy, M.; Ververken, C.; Beirnaert, E.; Hoefman, S.; Kolkman, J.; Vierboom, M.; Breedveld, E.; ‘t Hart, B.; Poelmans, S.; Bontinck, L.; et al. The preclinical pharmacology of the high affinity anti-IL-6R Nanobody®ALX-0061 supports its clinical development in rheumatoid arthritis. Arthritis Res. Ther. 2015, 17, 135. [CrossRef]

15. Kratz, F.; Elsadek, B. Clinical impact of serum proteins on drug delivery. J. Control. Release 2012, 161, 429-445. [CrossRef]

16. Vosjan, M.J.; Vercammen, J.; Kolkman, J.A.; Stigter-van Walsum, M.; Revets, H.; van Dongen, G.A. Nanobodies targeting the hepatocyte growth factor: Potential new drugs for molecular cancer therapy. Mol. Cancer Ther. 2012, 11, 1017-1025. [CrossRef] [PubMed]

17. Wu, J.; Fu, J.; Zhang, M.; Liu, D. AFM13: A first-in-class tetravalent bispecific anti-CD30/CD16A antibody for NK cell-mediated immunotherapy. J. Hematol. Oncol. 2015, 8, 96. [CrossRef] [PubMed]

18. Compte, M.; Harwood, S.L.; Muñoz, I.G.; Navarro, R.; Zonca, M.; Perez-Chacon, G.; Erce-Llamazares, A.; Merino, N.; TapiaGalisteo, A.; Cuesta, A.M.; et al. A tumor-targeted trimeric 4-1BB-agonistic antibody induces potent anti-tumor immunity without systemic toxicity. Nat. Commun. 2018, 9, 4809. [CrossRef] [PubMed]

19. Compte, M.; Harwood, S.L.; Erce-Llamazares, A.; Tapia-Galisteo, A.; Romero, E.; Ferrer, I.; Garrido-Martin, E.M.; Enguita, A.B.; Ochoa, M.C.; Blanco, B.; et al. An Fc-free EGFR-specific 4-1BB-agonistic Trimerbody Displays Broad Antitumor Activity in Humanized Murine Cancer Models without Toxicity. Clin. Cancer Res. 2021, 27, 3167-3177. [CrossRef]

20. Liu, H.F.; Ma, J.; Winter, C.; Bayer, R. Recovery and purification process development for monoclonal antibody production. MAbs Taylor Fr. 2010, 2, 480-499. [CrossRef]

21. Rodrigo, G.; Gruvegard, M.; Van Alstine, J.M. Antibody Fragments and Their Purification by Protein L Affinity Chromatography. Antibodies 2015, 4, 259-277. [CrossRef]

22. Noël, D.; Pelegrin, M.; Marin, M.; Biard-Piechaczyk, M.; Ourlin, J.C.; Mani, J.C.; Piechaczyk, M. In vitro and in vivo secretion of cloned antibodies by genetically modified myogenic cells. Hum. Gene Ther. 1997, 8, 1219-1229. [CrossRef]

23. Sanz, L.; Kristensen, P.; Blanco, B.; Facteau, S.; Russell, S.J.; Winter, G.; Alvarez-Vallina, L. Single-chain antibody-based gene therapy: Inhibition of tumor growth by in situ production of phage-derived human antibody fragments blocking functionally active sites of cell-associated matrices. Gene Ther. 2002, 9, 1049-1053. [CrossRef]

24. Blanco, B.; Holliger, P.; Vile, R.G.; Alvarez-Vallina, L. Induction of human T lymphocyte cytotoxicity and inhibition of tumor growth by tumor-specific diabody-based molecules secreted from gene-modified bystander cells. J. Immunol. 2003, 171, 1070-1077. [CrossRef] [PubMed]

25. Sanz, L.; Blanco, B.; Alvarez-Vallina, L. Antibodies and gene therapy: Teaching old 'magic bullets' new tricks. Trends Immunol. 2004, 25, 85-91. [CrossRef] [PubMed]

26. Alvarez-Vallina, L. Genetic approaches for antigen-selective cell therapy. Curr. Gene Ther. 2001, 1, 385-397. [CrossRef] [PubMed]

27. Sánchez-Martín, D.; Sanz, L.; Álvarez-Vallina, L. Engineering human cells for in vivo secretion of antibody and non-antibody therapeutic proteins. Curr. Opin. Biotechnol. 2011, 22, 924-930. [CrossRef] [PubMed]

28. Guijarro-Muñoz, I.; Compte, M.; Alvarez-Vallina, L.; Sanz, L. Antibody gene therapy: Getting closer to clinical application? Curr. Gene Ther. 2013, 13, 282-290. [CrossRef] [PubMed]

29. Bargou, R.; Leo, E.; Zugmaier, G.; Klinger, M.; Goebeler, M.; Knop, S.; Noppeney, R.; Viardot, A.; Hess, G.; Schuler, M.; et al. Tumor regression in cancer patients by very low doses of a T cell-engaging antibody. Science 2008, 321, 974-977. [CrossRef] [PubMed]

30. Martinelli, G.; Boissel, N.; Chevallier, P.; Ottmann, O.; Gökbuget, N.; Topp, M.S.; Fielding, A.K.; Rambaldi, A.; Ritchie, E.K.; Papayannidis, C.; et al. Complete Hematologic and Molecular Response in Adult Patients With Relapsed/Refractory Philadelphia Chromosome-Positive B-Precursor Acute Lymphoblastic Leukemia Following Treatment With Blinatumomab: Results From a Phase II, Single-Arm, Multicenter Study. J. Clin. Oncol. 2017, 35, 1795-1802. [CrossRef] [PubMed] 
31. Compte, M.; Blanco, B.; Serrano, F.; Cuesta, A.M.; Sanz, L.; Bernad, A.; Holliger, P.; Alvarez-Vallina, L. Inhibition of tumor growth in vivo by in situ secretion of bispecific anti-CEA $x$ anti-CD3 diabodies from lentivirally transduced human lymphocytes. Cancer Gene Ther. 2007, 14, 380-388. [CrossRef]

32. Compte, M.; Cuesta, A.M.; Sánchez-Martín, D.; Alonso-Camino, V.; Vicario, J.L.; Sanz, L.; Alvarez-Vallina, L. Tumor immunotherapy using gene-modified human mesenchymal stem cells loaded into synthetic extracellular matrix scaffolds. Stem Cells 2009, 27, 753-760. [CrossRef]

33. Compte, M.; Alonso-Camino, V.; Santos-Valle, P.; Cuesta, A.M.; Sánchez-Martín, D.; López, M.R.; Vicario, J.L.; Salas, C.; Sanz, L.; Alvarez-Vallina, L. Factory neovessels: Engineered human blood vessels secreting therapeutic proteins as a new drug delivery system. Gene Ther. 2010, 17, 745-751. [CrossRef]

34. Compte, M.; Alvarez-Cienfuegos, A.; Nuñez-Prado, N.; Sainz-Pastor, N.; Blanco-Toribio, A.; Pescador, N.; Sanz, L.; AlvarezVallina, L. Functional comparison of single-chain and two-chain anti-CD3-based bispecific antibodies in gene immunotherapy applications. Oncoimmunology 2014, 3, e28810. [CrossRef]

35. Mølgaard, K.; Compte, M.; Nuñez-Prado, N.; Harwood, S.L.; Sanz, L.; Alvarez-Vallina, L. Balanced secretion of anti-CEA $\times$ anti-CD3 diabody chains using the 2A self-cleaving peptide maximizes diabody assembly and tumor-specific cytotoxicity. Gene Ther. 2017, 24, 208-214. [CrossRef] [PubMed]

36. Blanco, B.; Compte, M.; Lykkemark, S.; Sanz, L.; Alvarez-Vallina, L. T Cell-Redirecting Strategies to 'STAb’ Tumors: Beyond CARs and Bispecific Antibodies. Trends Immunol. 2019, 40, 243-257. [CrossRef] [PubMed]

37. Iwahori, K.; Kakarla, S.; Velasquez, M.P.; Yu, F.; Yi, Z.; Gerken, C.; Song, X.T.; Gottschalk, S. Engager T cells: A new class of antigen-specific T cells that redirect bystander T cells. Mol. Ther. 2015, 23, 171-178. [CrossRef] [PubMed]

38. Velasquez, M.P.; Torres, D.; Iwahori, K.; Kakarla, S.; Arber, C.; Rodriguez-Cruz, T.; Szoor, A.; Bonifant, C.L.; Gerken, C.; Cooper, L.J.; et al. T cells expressing CD19-specific Engager Molecules for the Immunotherapy of CD19-positive Malignancies. Sci. Rep. 2016, 6, 27130. [CrossRef]

39. Bonifant, C.L.; Szoor, A.; Torres, D.; Joseph, N.; Velasquez, M.P.; Iwahori, K.; Gaikwad, A.; Nguyen, P.; Arber, C.; Song, X.T.; et al. CD123-Engager T Cells as a Novel Immunotherapeutic for Acute Myeloid Leukemia. Mol. Ther. 2016, 24, 1615-1626. [CrossRef]

40. Liu, X.; Barrett, D.M.; Jiang, S.; Fang, C.; Kalos, M.; Grupp, S.A.; June, C.H.; Zhao, Y. Improved anti-leukemia activities of adoptively transferred $\mathrm{T}$ cells expressing bispecific T-cell engager in mice. Blood Cancer J. 2016, 6, e430. [CrossRef]

41. Sahin, U.; Karikó, K.; Türeci, Ö. mRNA-based therapeutics-developing a new class of drugs. Nat. Rev. Drug Discov. 2014, 13, 759-780. [CrossRef]

42. Van Hoecke, L.; Roose, K. How mRNA therapeutics are entering the monoclonal antibody field. J. Transl. Med. 2019, 17, 54. [CrossRef]

43. Bushman, F.D. Retroviral Insertional Mutagenesis in Humans: Evidence for Four Genetic Mechanisms Promoting Expansion of Cell Clones. Mol. Ther. 2020, 28, 352-356. [CrossRef]

44. Fausther-Bovendo, H.; Kobinger, G.P. Pre-existing immunity against Ad vectors: Humoral, cellular, and innate response, what's important? Hum. Vaccines Immunother. 2014, 10, 2875-2884. [CrossRef] [PubMed]

45. Heine, A.; Juranek, S.; Brossart, P. Clinical and immunological effects of mRNA vaccines in malignant diseases. Mol. Cancer 2021, 20, 52. [CrossRef]

46. Karikó, K.; Buckstein, M.; Ni, H.; Weissman, D. Suppression of RNA recognition by Toll-like receptors: The impact of nucleoside modification and the evolutionary origin of RNA. Immunity 2005, 23, 165-175. [CrossRef]

47. Karikó, K.; Muramatsu, H.; Welsh, F.A.; Ludwig, J.; Kato, H.; Akira, S.; Weissman, D. Incorporation of pseudouridine into mRNA yields superior nonimmunogenic vector with increased translational capacity and biological stability. Mol. Ther. 2008, 16, 1833-1840. [CrossRef]

48. Deal, C.E.; Carfi, A.; Plante, O.J. Advancements in mRNA Encoded Antibodies for Passive Immunotherapy. Vaccines 2021, 9, 108. [CrossRef] [PubMed]

49. Stadler, C.R.; Bähr-Mahmud, H.; Celik, L.; Hebich, B.; Roth, A.S.; Roth, R.P.; Karikó, K.; Türeci, Ö.; Sahin, U. Elimination of large tumors in mice by mRNA-encoded bispecific antibodies. Nat. Med. 2017, 23, 815-817. [CrossRef] [PubMed]

50. Safety, Tolerability, Pharmacokinetics, and Pharmacodynamics of mRNA-1944 in Healthy Adults. Available online: https: / / clinicaltrials.gov /ct2/show / NCT03829384 (accessed on 23 September 2021).

51. Kose, N.; Fox, J.M.; Sapparapu, G.; Bombardi, R.; Tennekoon, R.N.; de Silva, A.D.; Elbashir, S.M.; Theisen, M.A.; HumphrisNarayanan, E.; Ciaramella, G.; et al. A lipid-encapsulated mRNA encoding a potently neutralizing human monoclonal antibody protects against chikungunya infection. Sci. Immunol. 2019, 4, eaaw6647. [CrossRef]

52. Thran, M.; Mukherjee, J.; Pönisch, M.; Fiedler, K.; Thess, A.; Mui, B.L.; Hope, M.J.; Tam, Y.K.; Horscroft, N.; Heidenreich, R.; et al. mRNA mediates passive vaccination against infectious agents, toxins, and tumors. EMBO Mol. Med. 2017, 9, 1434-1447. [CrossRef]

53. Tiwari, P.M.; Vanover, D.; Kevin, E.; Lindsay, K.E.; Bawage, S.S.; Kirschman, J.L.; Bhosle, S.; Lifland, W.A.; Zurla, C.; Santagelo, P.J Engineered mRNA-expressed antibodies prevent respiratory syncytial virus infection. Nat. Commun. 2018, 9, 3999. [CrossRef]

54. Hoecke, L.V.; Verbeke, R.; Vlieger, D.D.; Dewitte, H.; Roose, K.; Nevel, S.V.; Krysko, O.; Bachert, C.; Schepens, B.; Lentacker, I.; et al. mRNA Encoding a Bispecific Single Domain Antibody Construct Protects against Influenza A Virus Infection in Mice. Mol. Ther. Nucleic Acids 2020, 20, 777-787. [CrossRef] 